\title{
Review \\ Statin Therapy in Post-Operative Atrial Fibrillation: Focus on the Anti-Inflammatory Effects
}

\author{
Homa Nomani ${ }^{1}$, Amir Hooshang Mohammadpour 2,3 , Željko Reiner ${ }^{4}$, Tannaz Jamialahmadi ${ }^{5,6}$ \\ and Amirhossein Sahebkar 7,8,9,*
}

check for

updates

Citation: Nomani, H.;

Mohammadpour, A.H.; Reiner, Ž.;

Jamialahmadi, T.; Sahebkar, A. Statin

Therapy in Post-Operative Atrial

Fibrillation: Focus on the

Anti-Inflammatory Effects. $J$.

Cardiovasc. Dev. Dis. 2021, 8, 24.

https://doi.org/10.3390/jcdd8030024

Academic Editors: Gerhard Kostner and Karam Kostner

Received: 28 January 2021

Accepted: 21 February 2021

Published: 26 February 2021

Publisher's Note: MDPI stays neutral with regard to jurisdictional claims in published maps and institutional affiliations.

Copyright: (c) 2021 by the authors. Licensee MDPI, Basel, Switzerland. This article is an open access article distributed under the terms and conditions of the Creative Commons Attribution (CC BY) license (https:/ / creativecommons.org/licenses/by/ $4.0 /)$.
1 School of Pharmacy, Mashhad University of Medical Sciences, Mashhad 9179156314, Iran; Nomanih8@mums.ac.ir

2 Pharmaceutical Research Center, Pharmaceutical Technology Institute, Mashhad University of Medical Sciences, Mashhad 9179156314, Iran; Mohamadpoorah@mums.ac.ir

3 Department of Clinical Pharmacy, School of Pharmacy, Mashhad University of Medical Sciences, Mashhad 9179156314, Iran

4 Department of Internal Medicine, University Hospital Ceter Zagreb, School of Medicine University of Zagreb, 10000 Zagreb, Croatia; zreiner@kbc-zagreb.hr

5 Department of Food Science and Technology, Quchan Branch, Islamic Azad University, Quchan 9479176135, Iran; jamiat981@mums.ac.ir

6 Department of Nutrition, Mashhad University of Medical Sciences, Mashhad 9177948564, Iran

7 Biotechnology Research Center, Pharmaceutical Technology Institute, Mashhad University of Medical Sciences, Mashhad 9177948564, Iran

8 Applied Biomedical Research Center, Mashhad University of Medical Sciences, Mashhad 9177948564, Iran

9 Polish Mother's Memorial Hospital Research Institute (PMMHRI), 93-338 Lodz, Poland

* Correspondence: sahebkara@mums.ac.ir

Abstract: Background: Atrial fibrillation (AF) occurring after cardiac surgery, post-operative AF (POAF), is a serious and common complication of this treatment. POAF may be life-threatening and the available preventive strategies are insufficient or are associated with significantly increased risk of adverse effects, especially in long-term use. Therefore, more appropriate treatment strategies are needed. Methods: In this paper, the efficacy, safety, and other aspects of using statins in the prevention of POAF focusing on their anti-inflammatory effects are reviewed. Results: Recent studies have suggested that inflammation has a significant role in POAF, from the first AF episode to its serious complications including stroke and peripheral embolism. On the other hand, statins, the most widely used medications in cardiovascular patients, have pleiotropic effects, including anti-inflammatory properties. Therefore, they may potentially be effective in POAF prevention. Statins, especially atorvastatin, appear to be an effective option for primary prevention of POAF, especially in patients who had coronary artery bypass grafting (CABG), a cardiac surgery treatment associated with inflammation in the heart muscle. However, several large studies, particularly with rosuvastatin, did not confirm the beneficial effect of statins on POAF. One large clinical trial reported higher risk of acute kidney injury (AKI) following high-dose rosuvastatin in Chinese population. In this study, rosuvastatin reduced the level of C-reactive protein (CRP) but did not reduce the rate of POAF. Conclusion: Further studies are required to find the most effective statin regimen for POAF prevention with the least safety concern and the highest health benefits.

Keywords: atrial fibrillation; inflammation; cardiac surgery; statins; atorvastatin; rosuvastatin

\section{Introduction}

The occurrence of atrial fibrillation (AF) after cardiac surgery, post-operative AF (POAF), is a serious and common post-operative complication [1]. POAF may be lifethreatening [2] and the available preventive strategies are insufficient or are associated with significantly increased risk of adverse effects, especially in long-lasting treatment [3]. Therefore, finding more appropriate strategies is a concern. Recent studies have suggested 
that inflammation has a significant role in POAF, from the first episode of AF to serious complications including strokes and peripheral embolism [4]. Statins are the most widely used medications in cardiovascular patients and have many pleiotropic effects apart from their established low-density lipoprotein (LDL)-lowering activity [5-12]. In this paper, a summary of the role of inflammation in the POAF is presented as well as the evidence indicating anti-inflammatory effects of statins. The recent clinical evidence on the effects of statins on POAF are also extensively reviewed.

\section{The Role of Inflammation in AF}

Several epidemiologic studies confirmed the association between AF and inflammation as indicated by the elevation of inflammatory biomarkers like C-reactive protein (CRP) [13]. The peak CRP level occurs on the second post-operative day after cardiac surgery, and POAF typically occurs within the first three post-operative days [13]. However, the important question is how does surgery trigger the inflammation and how could this result in POAF. During cardiac surgery, inflammation could be induced by factors like surgical injury, myocardial ischemia and a hyper-adrenergic state [14]. Inflammation causes the production of inflammatory mediators: cytokines.

These markers also can be secreted by epicardial adipose tissue (EAT) and may have local pro-inflammatory effects on the atrial myocardium, which might cause cardiac arrhythmia [15].

Epicardial adipose tissue (EAT) is located along the myocardium and the visceral layer of the pericardium. It is considered to be an endocrine organ that releases proinflammatory cytokines associated with arrhythmia. Epicardial fat directly or indirectly promotes atrial fibrillation (AF) by atrial remodeling. It can penetrate the atrium and alter its electrophysiological structure (direct pathway) or modulate cardiac inflammation and oxidative stress in a paracrine fashion (indirect pathway). Additionally, the interaction between EAT and pulmonary veins is likely to have an arrhythmogenic effect and prevent AF $[15,16]$.

Cytokines can trigger changes in the atrium, i.e., electrical and structural remodeling of the atrium by different mechanisms [17]. These changes cause conduction heterogeneity and are predisposition for AF [18]. The mechanisms by which inflammation can cause the atrium remodeling and POAF include oxidative stress, myolysis, apoptosis, and reduction of connexin 40 and 43 [19], the gap junction proteins expressed in the atrium and involved in normal atrial conduction [20]. Abnormal calcium handling is another important mechanism that results in abnormal conduction and conduction heterogeneity [19]. Inflammation can trigger POAF, especially after coronary artery bypass grafting (CABG), as an intensive and aggressive cardiac surgery [21]. Therefore, drugs with anti-inflammatory properties may be potentially effective in primary prevention of POAF.

\section{Drugs with Anti-Inflammatory Properties and POAF}

The effectiveness of medical interventions to prevent or reduce the occurrence of POAF has been previously evaluated. Several anti-inflammatory agents such as nonsteroid antiinflammatory drugs (NSAIDs), steroid anti-inflammatory drugs, immunosuppressants, and statins can prevent POAF. In addition, colchicine, a drug used for gout management, can be safe and useful for peri-operative inhibition of inflammation and may also be effective in the prevention of POAF [22].

\section{Anti-Inflammatory Effects of Statins}

Statins are inhibitors of 3-hydroxy-3-methylglutaryl coenzyme A (HMG-CoA) reductase. They are designed to decrease blood cholesterol, particularly LDL-cholesterol $[23,24]$. However, already more than three decades ago, it was shown that they have several other beneficial effects, i.e., pleiotropic effects, independent from their cholesterol-lowering properties [23]. There are several mechanisms by which statins might be involved in preventing AF including the improvement of endothelial function, their antioxidative, 
and anti-inflammatory effects [13]. The focus of this paper is on anti-inflammatory effects of statins.

There are many in vitro and animal studies suggesting that statins have considerable anti-inflammatory properties [23]. Recent clinical studies suggest that this effect is beneficial and is independent of their lipid-lowering effect [23].

The most convincing clinical evidence indicating the anti-inflammatory effects of statins is provided by studies analyzing the blood levels of inflammatory biomarkers such as CRP [23]. Several large clinical trials indicated that statin therapy could significantly reduce CRP level compared with placebo [25-27]. Statins also reduce the level of proinflammatory cytokines such as tumor necrosis factor- $\alpha$ (TNF- $\alpha$ ), interleukin-1 (IL-1), and interleukin-6 (IL-6) [13].

Statins improve cardiometabolic status in patients with cardiovascular risk factors or overt cardiovascular diseases. Long-term statin therapy reduces EAT in patients with coronary artery disease. However, the role of short-time statin treatment on EAT volume in AF patients is still unclear [16].

Based on recent studies, the mechanisms by which statins exert their anti-inflammatory properties include reducing the number of inflammatory cells and cytokines, inhibiting the adhesion molecules, upregulation of the endothelial nitric oxide (NO), and inhibition of superoxide release [13].

\section{Statins in the Primary Prevention of POAF: The Review of Available Clinical Evidence}

There are several randomized clinical trials (RCTs) (Table 1) and meta-analyses (Table 2) that evaluated the effect of statin therapy on prevention of POAF. Some of these studies analyzed the changes in inflammatory markers to evaluate whether this effect is associated with anti-inflammatory effects of statins. Based on these studies, different aspects of statin therapy for primary prevention of POAF are discussed below. 
Table 1. Randomized clinical trials evaluating the effect of statins on the prevention of post-operative atrial fibrillation.

\begin{tabular}{|c|c|c|c|c|c|c|c|c|c|c|c|}
\hline Study Design & $\begin{array}{l}\mathrm{N} \text { of } \\
\text { Patients }\end{array}$ & Surgery & Drug & $\begin{array}{l}\text { Dose \& Rout } \\
\text { of Adminis- } \\
\text { tration }\end{array}$ & Duration & Control & Results & $\begin{array}{l}\text { Rate of Post-Operative } \\
\text { Atrial Fibrillation }\end{array}$ & Inf. Markers & Safety & Reference \\
\hline $\begin{array}{l}\text { R PC clinical } \\
\text { trial }\end{array}$ & 1922 & $\begin{array}{l}\text { elective CABG, } \\
\text { Aortic valve } \\
\text { surgery or both }\end{array}$ & rosuvastatin & $20 \mathrm{mg} / \mathrm{d}$ & $\begin{array}{l}\text { For up to } 8 \text { days } \\
\text { before surgery } \\
\text { until } 5 \text { day after } \\
\text { surgery }\end{array}$ & placebo & $\begin{array}{c}\text { No significant } \\
\text { differences between } \\
\text { groups (OR 1.04 95\% CI } \\
0.84-1.3 \text { p 0.72) }\end{array}$ & $\begin{array}{l}21.1 \% \text { in rosuvastatin } \\
\text { group } \\
\text { and } 20.5 \% \text { in placebo } \\
\text { group }\end{array}$ & $\begin{array}{l}\text { CRP levels were } \\
\text { lower } \\
\text { significantly }\end{array}$ & $\begin{array}{c}\text { More } \\
\text { postoperative } \\
\text { acute kidney } \\
\text { injury rate and } \\
\text { no beneficial } \\
\text { effect }\end{array}$ & [25] \\
\hline $\mathrm{R}$ clinical trial & 212 & $\begin{array}{c}\text { Elective } \\
\text { on-pump CABG }\end{array}$ & atorvastatin & \multicolumn{2}{|c|}{$\begin{array}{l}80 \mathrm{mg} / \mathrm{d} \text { For } 7 \text { days before surgery, } \\
\text { stopped the evening before, } \\
\text { resumed } 4 \mathrm{~h} \text { later with } 40 \mathrm{mg} / \mathrm{d}\end{array}$} & $\begin{array}{l}\text { Atorvastatin } \\
\quad 40 \mathrm{mg}\end{array}$ & $\begin{array}{c}\text { A trend toward a } \\
\text { decrease in POAF was } \\
\text { observed with } \\
\text { high-dose statin but did } \\
\text { not reach to } \\
\text { significance }\end{array}$ & $\begin{array}{l}23.6 \% \text { in atorvastatin } \\
40 \mathrm{mg} \text { group } \\
\text { and } 15.8 \% \text { in } \\
\text { atorvastatin } 80 \mathrm{mg} \\
\text { group }\end{array}$ & $\begin{array}{l}\text { Mean values of } \\
\text { CRP and IL6 } \\
\text { were not } \\
\text { different } \\
\text { between } 2 \text { doses }\end{array}$ & & [28] \\
\hline $\begin{array}{c}\text { R DB PC } \\
\text { clinical trial }\end{array}$ & $\begin{array}{c}199 \\
\text { statin-naïve } \\
416 \text { statin } \\
\text { user }\end{array}$ & cardiac surgery & atorvastatin & $\begin{array}{r}80 \\
\text { At the day be } \\
\text { morning of si } \\
40\end{array}$ & $\begin{array}{l}\text { g/d } \\
\text { re surgery or the } \\
\text { ery followed by } \\
\text { ig/d }\end{array}$ & placebo & $\begin{array}{l}\text { POAF increased in } \\
\text { statin-native patients } \\
\text { and statin-native } \\
\text { patients with chronic } \\
\text { kidney disease vs. } \\
\text { control, but in all } \\
\text { patients, statin did not } \\
\text { affect POAF (RR, } 1.11 \\
0.90,1.38 \text { P } 0.38 \text { ) }\end{array}$ & $\begin{array}{l}37.3 \% \text { in atorvastatin } \\
\text { group } \\
\text { And } 33.6 \% \text { in placebo } \\
\text { group }\end{array}$ & & & [29] \\
\hline P R clinical trial & 60 & $\begin{array}{l}\text { Elective isolated } \\
\text { CABG }\end{array}$ & Atorvastatin & $40 \mathrm{mg} / \mathrm{d}$ & $\begin{array}{l}\text { from } 6 \mathrm{~h} \mathrm{PO} \text { and } \\
\text { continued }\end{array}$ & Non-statin & $\begin{array}{c}\text { Significant lower rate of } \\
\text { POAF (OR 0.512 95\% } \\
\text { CI 0.005- } 0.517 \\
\text { p 0.012) }\end{array}$ & $\begin{array}{l}16.7 \% \text { in statin group } \\
\text { and } 43.3 \% \text { in placebo } \\
\text { group }\end{array}$ & & & [31] \\
\hline$\underset{\text { trial }}{\mathrm{R} P C \text { clinical }}$ & $\begin{array}{l}500 \text { stable } \\
\text { CAD } \\
\text { patients }\end{array}$ & $\begin{array}{l}\text { Non-cardiac } \\
\text { surgery }\end{array}$ & Atorv & tin reload peri-o & ratively & Placebo & $\begin{array}{l}\text { Significant lower rate of } \\
\text { POAF (p 0.0003) }\end{array}$ & $\begin{array}{l}6.8 \% \text { in statin group } \\
\text { and } 17 \% \text { in placebo } \\
\text { group }\end{array}$ & & $\begin{array}{l}\text { Lower rate of } \\
30 \text {-days } \\
\text { incidence of } \\
\text { major adverse } \\
\text { cardiac events }\end{array}$ & [32] \\
\hline $\begin{array}{c}\text { R DB PC } \\
\text { Clinical trial }\end{array}$ & 60 & $\begin{array}{c}\text { Isolated } \\
\text { first-time CABG }\end{array}$ & Atorvastatin & $40 \mathrm{mg} / \mathrm{d}$ & $\begin{array}{l}\text { From } 14 \text { days } \\
\text { before surgery } \\
\text { afterwards }\end{array}$ & Placebo & $\begin{array}{l}\text { Significant lower rate of } \\
\text { POAF compared to } \\
\text { placebo ( } 3.3 \% \text { vs. } 23 \% \\
\text { p } 0.02)\end{array}$ & $\begin{array}{l}3.3 \% \text { in atorvastatin } \\
\text { group and } 23 \% \text { in } \\
\text { placebo group }\end{array}$ & $\begin{array}{l}\text { CRP levels were } \\
\text { significantly } \\
\text { lower pre- and } \\
\text { post-operatively } \\
\text { in statin group }\end{array}$ & & [33] \\
\hline $\mathrm{R}$ clinical trial & $\begin{array}{l}90 \\
\text { (30 in each } \\
\text { group) }\end{array}$ & Elective CABG & Atorvastatin & $20 \mathrm{mg} / \mathrm{d}$ & $\begin{array}{l}\text { From } 3 \text { weeks } \\
\text { before surgery } \\
\text { afterwards }\end{array}$ & $\begin{array}{l}\text { Non-statin and } \\
\text { non- } \\
\text { corticosteroid }\end{array}$ & $\begin{array}{l}\text { Significant lower rate of } \\
\text { POAF }\end{array}$ & $\begin{array}{l}13.8 \% \text { in atorvastatin } \\
\text { group, } 10.3 \% \text { in MP } \\
\text { group and } 39.3 \% \text { in } \\
\text { placebo group }\end{array}$ & $\begin{array}{l}\text { PO IL-6 levels } \\
\text { were lower } \\
\text { compared to } \\
\text { control }\end{array}$ & $\begin{array}{l}\text { Increased PO } \\
\text { cardiac index } \\
\text { and reduced } \\
\text { ICU stay }\end{array}$ & [34] \\
\hline
\end{tabular}


Table 1. Cont.

\begin{tabular}{|c|c|c|c|c|c|c|c|c|c|c|c|}
\hline Study Design & $\begin{array}{c}\mathrm{N} \text { of } \\
\text { Patients }\end{array}$ & Surgery & Drug & $\begin{array}{l}\text { Dose \& Rout } \\
\text { of Adminis- } \\
\text { tration }\end{array}$ & Duration & Control & Results & $\begin{array}{l}\text { Rate of Post-Operative } \\
\text { Atrial Fibrillation }\end{array}$ & Inf. Markers & Safety & Reference \\
\hline $\begin{array}{l}\text { R single-blind } \\
\text { Clinical trial }\end{array}$ & 104 & $\begin{array}{l}\text { CABG or Aortic } \\
\text { valve } \\
\text { replacement }\end{array}$ & Atorvastatin & $80 \mathrm{mg} / \mathrm{d}$ & $\begin{array}{l}\text { From } 7 \text { days } \\
\text { before surgery }\end{array}$ & $\begin{array}{l}\text { Atorvastatin } \\
10 \mathrm{mg} / \mathrm{d}\end{array}$ & $\begin{array}{l}\text { A non-significant } \\
\text { reduction in POAF by } \\
\text { high-dose statin vs. } \\
\text { low-dose statin }\end{array}$ & $\begin{array}{l}29 \% \text { in high dose group } \\
\text { vs. } 36 \% \\
\text { p } 0.43\end{array}$ & & & [35] \\
\hline $\begin{array}{c}\mathrm{R} P C \text { clinical } \\
\text { trial }\end{array}$ & 100 & $\begin{array}{c}\text { Elective } \\
\text { on-pump CABG }\end{array}$ & atorvastatin & $20 \mathrm{mg} / \mathrm{d}$ & $\begin{array}{l}\text { From } 7 \text { days } \\
\text { before surgery }\end{array}$ & placebo & $\begin{array}{c}\text { A significant reduction } \\
\text { in POAF by statin vs. } \\
\text { placebo }(\mathrm{OR}=0.235 \\
p=0.007)\end{array}$ & $\begin{array}{c}(18 \% \text { in statin group vs. } \\
41 \% \text { in placebo group } \\
\text { p } 0.017 \text { ) }\end{array}$ & $\begin{array}{l}\text { PO peak CRP } \\
\text { levels were } \\
\text { lower in statin } \\
\text { group }\end{array}$ & & [27] \\
\hline $\begin{array}{l}\text { R PC clinical } \\
\text { trial }\end{array}$ & 200 & Elective CABG & Rosuvastatin & $20 \mathrm{mg} / \mathrm{d}$ & $\begin{array}{l}\text { From } 7 \text { days } \\
\text { before surgery }\end{array}$ & placebo & $\begin{array}{c}\text { A significant reduction } \\
\text { in POAF by statin vs. } \\
\text { placebo (OR } 0.4695 \% \text { CI } \\
0.22-0.94 \text { P } 0.03 \text { ) }\end{array}$ & $\begin{array}{l}18 \% \text { in rosuvastatin } \\
\text { group } \\
\text { and } 35 \% \text { in placebo } \\
\text { group }\end{array}$ & $\begin{array}{c}\text { Lower CRP } \\
\text { increasement } \\
\text { above than a } \\
\text { AF-predictor } \\
\quad \text { levels }\end{array}$ & & [26] \\
\hline $\begin{array}{l}\text { R fully-blinded } \\
\text { PC clinical trial }\end{array}$ & 200 & $\begin{array}{l}\text { On-pump CABG } \\
\text { or valve surgery }\end{array}$ & atorvastatin & $40 \mathrm{mg} / \mathrm{d}$ & $\begin{array}{l}\text { From } 7 \text { days } \\
\text { before surgery }\end{array}$ & placebo & $\begin{array}{c}\text { A significant reduction } \\
\text { in POAF by statin vs. } \\
\text { placebo (OR } 0.3995 \% \text { CI } \\
0.18-0.85 \text { P } 0.017 \text { ) }\end{array}$ & $\begin{array}{c}(35 \% \text { versus } 57 \% \\
\quad p=0.003)\end{array}$ & $\begin{array}{l}\text { Peak CRP levels } \\
\text { were lower in } \\
\text { patients without } \\
\mathrm{AF}(p=0.01), \\
\text { irrespective of } \\
\text { statin use }\end{array}$ & $\begin{array}{c}\text { Similar major } \\
\text { adverse cardiac } \\
\text { and } \\
\text { cerebrovascular } \\
\text { events at } 30 \text { days }\end{array}$ & [36] \\
\hline
\end{tabular}

Abbreviations: CABG (Coronary artery bypass grafting), CRP (c-reactive protein), N (number), POAF (Postoperative atrial fibrillation), RR (risk ratio), OR (odds ratio)

Table 2. Meta-analyses evaluating the effect of statins on the prevention of post-operative atrial fibrillation.

\begin{tabular}{|c|c|c|c|c|c|c|c|}
\hline $\begin{array}{l}\mathrm{N} \text { and Design of Included } \\
\text { Studies Evaluating POAF }\end{array}$ & N of Sample & $\begin{array}{l}\text { Was Effective POAF } \\
\text { Risk Reduction? }\end{array}$ & $\begin{array}{c}\text { In Which Surgery Type } \\
\text { Are Statins More } \\
\text { Effective? }\end{array}$ & $\begin{array}{l}\text { Which Statin Is More } \\
\text { Effective }\end{array}$ & $\begin{array}{l}\text { Other Benefits or Any } \\
\text { Hazards }\end{array}$ & $\begin{array}{c}\text { Changes in } \\
\text { Inflammatory Markers }\end{array}$ & Reference \\
\hline $18 \mathrm{RCT}$ & 3995 & $\begin{array}{c}\text { Yes } \\
\text { RR } 0.69 \text { 95\%CI } 0.56-0.86 \\
\text { p } 0.001\end{array}$ & Only in CABG & NA & $\begin{array}{l}\text { Not associated with reduced } \\
\text { or increased risk of AKI or MI, } \\
\text { but there was an increased } \\
\text { trend of higher AKI in } \\
\text { patients with valve surgery }\end{array}$ & $\begin{array}{l}\text { Significant decrease in } \\
\text { inflammatory response }\end{array}$ & [37] \\
\hline $20 \mathrm{RCT}$ & 4338 & $\begin{array}{c}\text { Yes } \\
\text { RR } 0.50 \\
p=0.0004\end{array}$ & $\begin{array}{l}\text { Isolated CABG, not } \\
\text { effective in combined } \\
\text { surgeries }\end{array}$ & Ator & $\begin{array}{l}\text { Not effective in post-operative } \\
\text { AKI or MI }\end{array}$ & NA & [38] \\
\hline $12 \mathrm{RCT}$ & 1116 & $\begin{array}{c}\text { Yes, } \\
\text { OR } 0.50 \text { 95\%CI } 0.41-0.61 \\
p=0.00001\end{array}$ & CABG & NA & NA & NA & [39] \\
\hline 15 Clinical trials & 9369 & $\begin{array}{c}\text { Yes } \\
\text { OR } 0.48195 \% \text { CI } \\
0.345-0.672 p=0.00\end{array}$ & $\begin{array}{l}\text { Only studies evaluating } \\
\text { post-CABG AF included }\end{array}$ & NA & $\begin{array}{l}\text { Significant decrease in } \\
\text { cerebral circulation disorders }\end{array}$ & $\begin{array}{l}\text { Significant decrease in } \\
\text { inflammatory markers }\end{array}$ & [40] \\
\hline
\end{tabular}


Table 2. Cont.

\begin{tabular}{|c|c|c|c|c|c|c|c|}
\hline $\begin{array}{l}\mathrm{N} \text { and Design of Included } \\
\text { Studies Evaluating POAF }\end{array}$ & N of Sample & $\begin{array}{l}\text { Was Effective POAF } \\
\text { Risk Reduction? }\end{array}$ & $\begin{array}{c}\text { In Which Surgery Type } \\
\text { Are Statins More } \\
\text { Effective? }\end{array}$ & $\begin{array}{l}\text { Which Statin Is More } \\
\text { Effective }\end{array}$ & $\begin{array}{l}\text { Other Benefits or Any } \\
\text { Hazards }\end{array}$ & $\begin{array}{c}\text { Changes in } \\
\text { Inflammatory Markers }\end{array}$ & Reference \\
\hline $\begin{array}{c}3 \text { RCTs with low-risk of } \\
\text { bias }\end{array}$ & 2637 & No & NA & NA & $\begin{array}{l}26 \% \text { increase in AKI. } \\
\text { No association between statin } \\
\text { therapy and risk of MI }\end{array}$ & NA & [41] \\
\hline $12 \mathrm{RCT}$ & 2980 & $\begin{array}{c}\text { Yes } \\
\text { 0R } 0.4295 \% \text { CI } 0.27-0.66 \\
\text { p } 0.0001\end{array}$ & $\begin{array}{l}\text { Only studies evaluating } \\
\text { post-CABG AF included }\end{array}$ & Only Ator not Rosu & NA & NA & [42] \\
\hline $\begin{array}{l}\text { All related published } \\
\text { study }\end{array}$ & NA & $\begin{array}{c}\text { Yes } \\
\text { Homogenous OR 0.37 } \\
\text { 95\%CI 0.28-0.51 } p<0.0001\end{array}$ & NA & NA & NA & NA & [43] \\
\hline $\begin{array}{c}12 \text { ( } 3 \text { meta-analysis, } 5 \text { RCTs } \\
\text { and } 4 \text { retrospective } \\
\text { studies) }\end{array}$ & NA & $\begin{array}{c}\text { Pre-operative statin use, } \\
\text { yes }\end{array}$ & NA & NA & $\begin{array}{c}\text { Significant reduction in risk of } \\
\text { stroke }\end{array}$ & $\begin{array}{l}\text { Reduced levels of } \\
\text { inflammatory markers }\end{array}$ & [44] \\
\hline 12 RCTs & 1765 & $\begin{array}{c}\text { Pre-operative statin use, } \\
\text { yes } \\
\text { OR } 0.5495 \% \text { CI } 0.43-0.67 \\
p<0.01\end{array}$ & NA & NA & $\begin{array}{l}\text { No reduction in MI or renal } \\
\text { failure } \\
\text { No major or minor side effect } \\
\text { of statins }\end{array}$ & NA & [45] \\
\hline 12 RCTs & NA & $\begin{array}{c}\text { Yes } \\
\text { RR } 0.50 \text { 95\%CI } 0.35-0.73\end{array}$ & NA & NA & NA & NA & [47] \\
\hline 8 RCTs & 1156 & $\begin{array}{c}\text { Yes, it reduce the } \\
\text { new-onset POAF } \\
\text { OR } 0.44 \text { 95\%CI 0.29-0.68 } \\
p<0.0002\end{array}$ & NA & Ator & NA & Reduced & [48] \\
\hline $\begin{array}{l}\text { 26: RCTs and } \\
\text { observational studies }\end{array}$ & 28,772 & $\begin{array}{c}\text { In pre-operative statin use, } \\
\text { yes } \\
\text { OR } 0.7295 \% \text { CI } 0.59-0.87\end{array}$ & $\begin{array}{l}\text { post-CABG studies } \\
\text { included }\end{array}$ & NA & $\begin{array}{l}\text { No significant changes in } \\
\text { odds for renal failure }\end{array}$ & NA & [45] \\
\hline RCTs & NA & $\begin{array}{c}\text { Yes } \\
\text { RR } 0.70 .54-0.91\end{array}$ & NA & Rosu & NA & $\begin{array}{c}\text { It was effective } \\
\text { especially in patients } \\
\text { with higher CRP levels }\end{array}$ & [49] \\
\hline
\end{tabular}

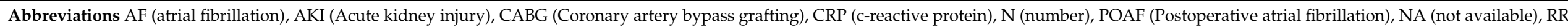
(risk ratio), OR (odds ratio). 


\subsection{Statin Effectiveness}

Several RCTs [26-34,36] and meta-analyses [37-40,42-49] have shown that pre- or peri-operative statin therapy is effective in lowering the risk of POAF incidence with a range between 30\% [49] and 59\% [46] compared with placebo, non-statin, or low-dose statins, regardless of statin type, dose, and duration or surgery type. Statin therapy reduced the levels of inflammatory markers, especially CRP levels (Tables 1 and 2) [50]. However, there are several limitations to the current data regarding statins for preventing AF, which are discussed below. As well, it is necessary to discuss different aspects of optimal statin therapy for POAF prevention and such a comprehensive discussion on drug selection, dose response, effectiveness associated to surgery type, and safety considerations will follow.

As we noted before, there are several limitations to the current data regarding statins for AF prevention, discussed here. First, a proportion of the current data are subgroup or post hoc analyses of randomized trials, of which some of them were not designed for the development of AF as a primary end point. Second, significant heterogeneity exists between and within studies on the method and the length of AF diagnosis or monitoring, which could significantly affect the rate of reported or diagnosed AF. Another important source of heterogeneity between studies may be the AF history of the study population, since primary prevention from $\mathrm{AF}$ is different from secondary prevention. Furthermore, patients who experienced AF are more prone to POAF occurrence [51]. Third, the type and the dose of statins were not systematically reported. A wide range of therapeutic potency, dosing regimens, and ethnic-based efficacy within this class of medications introduces potential statistical confounders. Finally, there are often contradictory results among meta-analyses, randomized, and observational studies, which confound any conclusions drawn [14]. There are some studies that showed no significant relation between statin therapy and POAF risk reduction. However, most of these studies were observational studies [52] and their results are not as reliable as experimental data because of more risk of bias or more detection of preexisting or asymptomatic AF. In addition, there were few clinical trials and just one meta-analysis failed to find statin therapy useful in POAF reduction. The most important trial with negative results was the STICS (statin therapy in cardiac surgery) trial. This trial was the largest, well-designed study, which used high-dose rosuvastatin in Chinese patients and led to significantly more post-operative acute kidney injury (AKI) [25]. The negative results of this study are discussed later. Interestingly, the only one meta-analysis, which failed to find statin therapy useful in reducing POAF rate [41], was greatly influenced by the STICS trial. However, two most recent meta-analyses results, which included this large trial, remained positive. These recent meta-analyses showed that statins were able to decrease the risk of POAF by $30-50 \%[37,38]$. However, these meta-analyses confirmed the effectiveness of statins only in post-CABG patients [37,38]. Other trials had some limitations, which might affect their results. In the Billings et al. study, POAF was not an end point. As well, the majority of the population in this placebo-controlled study were statin users by the time of randomization. These patients resumed their pre-study statin regimen on post-operative day 2 [29], regardless of their study group, placebo, or statin group. Such a study design could greatly influence their results. In addition, they initiated statin therapy from the day before surgery, while almost all of the studies with POAF end point initiated statin therapy from a few days before surgery. Another two studies that failed to find statin therapy useful in POAF reduction did not compare statins with placebo or usual care. They compared high-dose atorvastatin with medium or low dose of that. Indeed, the results of these dose-comparing studies cannot evaluate statin efficacy.

Overall, statin therapy appeared to be an effective option for primary prevention of POAF [48], especially in CABG patients.

As previous studies indicated, there is a significant reduction in the probability of atrial fibrillation following open heart surgery with statin therapy. It is suggested that peri-operative statin treatment has no adverse side effects and its beneficial implications preponderate the potential risks. Also, according to the available guidelines, pre-operative 
statin therapy and post-operative re-initiation appear to be reasonable in high-risk patients [53].

\subsection{Drug Selection and Effectiveness}

Most of the studies confirming statins' efficacy in reducing POAF risk were carried out with atorvastatin [27,30-34,36]. However, there are studies using other statins such as rosuvastatin [26], simvastatin [38], or pravastatin [38,54] but the results on the efficacy of these statins are conflicting. These results could be explained by different properties among different statins, especially pleiotropic effects such as anti-inflammatory properties [4]. However, the number of studies focusing on a specific statin or comparing their effects on AF prevention is still insufficient, and this fact might affect the results.

Two recent meta-analyses of RCTs found a significant association between statin therapy and decreased risk of POAF, particularly in the atorvastatin users [38,42]. These studies failed to show any association between POAF risk reduction and rosuvastatin [38,42] or simvastatin [38]. The largest RCT, which rejected rosuvastatin efficacy in POAF reduction, was the STICS trial [25]. This trial was conducted on a Chinese population and resulted in these conflicting findings. There are some explanations for these results. One possible explanation regards the race of the patients, who were Chinese and received as high as $20 \mathrm{mg}$ daily rosuvastatin or placebo. According to a previous study, lower dosages of statins are needed in Asians than Westerners. When the same doses are administered, Asian patients show higher plasma levels of rosuvastatin and its metabolites than Westerners [55]. Therefore, Chinese people may tolerate rosuvastatin less at $20 \mathrm{mg} /$ day than Westerners. This possibility partially confirmed when rosuvastatin was effective in POAF risk reduction when used in European people with the same dosage [26]. In addition, random allocation to $20 \mathrm{mg}$ of daily rosuvastatin significantly reduced AF risks within the JUPITER (justification for the use of statins in primary prevention: an intervention trial evaluating rosuvastatin) trial, which was conducted in the United States on patients with underlying inflammation (CRP higher than $2 \mathrm{mg} / \mathrm{L}$, without high low-density lipoprotein) [56]. However, $10 \mathrm{mg}$ of daily rosuvastatin effectively prevented AF after catheter ablation in another Chinese trial, conducted on heart failure (HF) patients [57]. In any case, well-designed RCTs are needed to find the most effective treatment protocol of statins in multi-national patients after cardiac surgery.

Another possible explanation for the conflicting results of the STICS trial is that previous trials included only patients who were not statin users before the study. However, in the STICS trial, 653 of the 1922 patients (34\%), including the placebo group, had used statins before recruitment [38]. Interestingly, another large trial that failed to show statin efficacy in POAF prevention included as high as $67 \%$ of statin-using patients [29]. However, we need more evidence to show whether statin therapy has a different effect between statin-naive patients and pre-study statin users [38]. After all, as discussed before, the resumption time of pre-study statin regimen can be a determinative factor in the results of such studies. However, a pre-specified subgroup analysis of the STICS trial failed to show any significant association between previous statin use and rosuvastatin efficacy in POAF prevention [25].

A clinical study comparing the effect of atorvastatin with rosuvastatin on POAF concluded that rosuvastatin or atorvastatin before surgery has a similar effect on preventing POAF [58]. It is notable that their study was a small study without any control group.

Concerning other statins, a large meta-analysis indicated that atorvastatin was more effective than pravastatin in reducing the rate of AF and using pravastatin failed to show protective effects (odds ratio (OR) 1.03, 95\% confidence interval (CI) 0.77-1.37) [59]. However, this meta-analysis included all RCTs evaluating statin effectiveness in all types of AF, including POAF. This different effect of atorvastatin and pravastatin could be due to their different chemical properties. The higher lipophilicity of atorvastatin could have led to a higher affinity for the cardiac cellular membrane. As a result, more penetration 
to the cardiac muscle cells occurs. Therefore, it is more effective in reducing AF than a hydrophilic statin such as pravastatin and rosuvastatin $[60,61]$.

\subsection{Dose Response}

It appears that statins exert their anti-arrhythmic properties due to their pleiotropic effect [39], which is dose-dependent. Very low doses of statins may lack pleiotropic effect and higher doses show higher pleiotropic effect [62]. Therefore, it is expected that higher statin dosage would be associated with more POAF reduction. However, the pleiotropic effect is not the only anti-arrhythmic mechanism of statins. Clinical studies led to conflicting or even surprising results. For instance, a meta-analysis of 20 RCTs concluded that statins effectively prevented AF and this AF risk reduction was dosedependent [59]. Surprisingly, a subgroup analysis of RCTs showed that statin therapy was more effective in lower doses, particularly in the dose range of $10-40 \mathrm{mg} /$ day of atorvastatin (OR $0.29,95 \%$ CI 0.19-0.45) [59]. It is notable that the focus of this meta-analysis was not on POAF and included studies evaluating primary or secondary prevention from AF. However, the least statin dose, which has been used effectively in RCTs at new-onset POAF reduction, was $20 \mathrm{mg} / \mathrm{d}$ of atorvastatin (Table 1). As well, there are studies indicating that anti-inflammatory effect of statins is not dose-dependent [63], despite their pleiotropic effect. Additionally, other facts should be considered before discussing the results of the mentioned meta-analyses. First, the results on high-dose atorvastatin are inconsistent. Second, explanations for such conflicting results could be the following possibilities. The selection of high-dose statins may reflect the more severe conditions or more susceptibility of patients to $\mathrm{AF}$ in the study population. In these patients, inflammation has a less important role in AF occurrence, and the failure of high-dose statins in reducing POAF risk may be due to these severe conditions. As well, the usage of high-dose statins greatly increases the risk of drug interactions. As a result, it can reduce tolerability in the study population and may increase patient dropout rate. Therefore, it can affect the study results.

However, the results of some studies do not agree with our assumption about doseresponse pattern of statins. Two studies, which compared high-dose with medium- or lowdose atorvastatin, showed no considerable differences in reducing the risk of POAF [28,46]. Similarly, another meta-analysis, which included eight RCTs evaluating the efficacy of statins on POAF occurrence, concluded that the dose of statins was not associated with risk reduction [64].

On the other hand, the results of some studies indicated that higher doses of statins cause better results. For instance, a retrospective study on patients who had CABG or valve surgery showed that the patients who were treated with simvastatin $>20 \mathrm{mg}$ daily had $36 \%$ lower odds of POAF (OR $0.64,95 \%$ CI 0.43 to $0.6 ; p=0.03$ ) in comparison to those receiving lower dosages. Indeed, statin therapy with higher doses reduces the occurrence of POAF more efficiently [65].

After all, the current data fail to support more effectiveness of higher doses of statins. However, the majority of current data originate from non-placebo-controlled trials or subgroup analysis of few studies. Therefore, there is a need for well-designed studies to determine the optimum dose of statins for POAF prevention.

\subsection{Effectiveness Associated with Surgery Type}

Most of the trials confirming statin efficacy in POAF reduction were done on CABG and heart valve surgeries patients, isolated or combined (Table 1). However, some trials show statin efficacy also in other types of surgery including catheter ablation [57] or even in non-cardiac surgical procedures in high-risk patients [32].

Some meta-analyses have compared statin efficacy in POAF reduction between CABG and combined or isolated heart valve surgery. The results on statin efficacy in postCABG AF reduction are consistent and show that statins are more effective in CABG patients $[38,39,42]$. CABG is a major surgery with more intensive inflammatory conditions. 
Therefore, the association between statin efficacy and post-CABG AF may be due to the association between inflammation, $\mathrm{CABG}$, and AF.

\subsection{Safety}

There are several trials with statins without reporting any major side effect (Tables 1 and 2). However, a recent large RCT, the STICS trial, showed that AKI occurred more frequently in the statin group [25]. The STICS trial was performed on Chinese patients who had cardiac surgery and were randomized to receive rosuvastatin $20 \mathrm{mg}$ daily or placebo. This finding is in contrast to other trials. Billings et al. failed to show any relation between high-dose statin therapy and AKI [29], which was confirmed by two recent meta-analyses [38,53]. The only meta-analysis that confirmed the association between statin therapy and postoperative AKI in patients without renal dysfunction was greatly influenced by the STICS trial [41].

Anyway, the results of the STICS trial can be explained by the lesser tolerability of Chinese patients to high doses of rosuvastatin. There are some trials showing that the plasma levels of rosuvastatin and its metabolites were significantly higher in Asian, especially Chinese, populations [55,66-68]. As well, statins are metabolized with cytochrome p450, component CYP3A4, which can be a great potential source of drug interactions. High doses of statins, such as used in the STICS trial, greatly increase the risk of drug interactions leading to a significant increase in the serum levels of statins. As a result, the elevated levels of statins increase the risk and rate of side effects such as rhabdomyolysis. As is well known, rhabdomyolysis can lead to AKI [69]. Therefore, clinicians should be aware of such a drug interaction to prevent this potential side effect.

\subsection{Other Benefits}

Xia et al. showed that 500 stable coronary artery disease (CAD) patients, who underwent non-cardiac surgery, benefited from peri-operative atorvastatin reload. The statin group showed a lower rate of POAF and a lower incidence of major adverse cardiac events 30 days following surgery [32]. Moreover, a meta-analysis showed that pre-operative statin therapy was related to reduced stroke risk [44]. However, two other meta-analyses failed to find any association between statin therapy before surgery and reduced myocardial infarction (MI) rate $[38,53]$.

Reduction in AF duration was documented in a trial that was carried out on patients undergoing isolated heart valve surgery and receiving $40 \mathrm{mg}$ of atorvastatin preoperatively [30]. In addition, several RCTs and meta-analyses showed that the statin group had a shorter length of ICU or hospital stay $[32,34,36,38,40,42,63]$.

\section{Conclusions}

Statins, especially atorvastatin, in a special dose range, appear to be an effective option for POAF primary prevention, especially in patients who had CABG, which is an intensive heart surgery procedure associated with inflammation in the heart. However, there are few large studies indicating no beneficial effect of statins, especially rosuvastatin. One large clinical trial reported a higher risk of AKI following high-dose rosuvastatin in a Chinese population. In this study, however, rosuvastatin reduced the level of CRP but could not reduce the rate of POAF. Although several RCTs and meta-analyses have evaluated the efficacy of statins in POAF prevention, further studies are needed to find the most effective statin regimen for POAF prevention with the least safety considerations and the highest health benefits.

Author Contributions: A.H.M. and A.S. conceived the study. H.N., T.J. and Ž.R. wrote the manuscript. A.S. and A.H.M. revised the manuscript draft. All authors have read and agreed to the published version of the manuscript.

Funding: This research received no external funding. 
Acknowledgments: The authors would like to thank Seyed Mohammad Hassan Moallem for his help in editing this manuscript.

Conflicts of Interest: The authors declare no conflict of interest.

\section{References}

1. Marik, P.E.; Fromm, R. The efficacy and dosage effect of corticosteroids for the prevention of atrial fibrillation after cardiac surgery: A systematic review. J. Crit. Care 2009, 24, 458-463. [CrossRef] [PubMed]

2. Deftereos, S.; Giannopoulos, G.; Papoutsidakis, N.; Panagopoulou, V.; Kossyvakis, C.; Raisakis, K.; Cleman, M.W.; Stefanadis, C. Colchicine and the Heart. J. Am. Coll. Cardiol. 2013, 62, 1817-1825. [CrossRef]

3. Calò, L.; Martino, A.; Sciarra, L.; Ciccaglioni, A.; De Ruvo, E.; De Luca, L.; Sette, A.; Giunta, G.; Lioy, E.; Fedele, F. Upstream Effect for Atrial Fibrillation: Still a Dilemma? Pacing Clin. Electrophysiol. 2010, 34, 111-128. [CrossRef] [PubMed]

4. Lappegård, K.T.; Hovland, A.; Pop, G.A.M.; Mollnes, T.E. Atrial Fibrillation: Inflammation in Disguise? Scand. J. Immunol. 2013, 78, 112-119. [CrossRef] [PubMed]

5. Afshari, A.R.; Mollazadeh, H.; Henney, N.C.; Jamialahmad, T.; Sahebkar, A. Effects of statins on brain tumors: A review. Semin Cancer Biol. 2020. [CrossRef]

6. Bagheri, H.; Ghasemi, F.; Barreto, G.E.; Sathyapalan, T.; Jamialahmadi, T.; Sahebkar, A. The effects of statins on microglial cells to protect against neurodegenerative disorders: A mechanistic review. BioFactors 2020, 46, 309-325. [CrossRef] [PubMed]

7. Dehnavi, S.; Sohrabi, N.; Sadeghi, M.; Lansberg, P.; Banach, M.; Al-Rasadi, K.; Johnston, T.P.; Sahebkar, A. Statins and autoimmunity: State-of-the-art. Pharmacol. Ther. 2020, 214, 107614. [CrossRef]

8. Gorabi, A.M.; Kiaie, N.; Bianconi, V.; Jamialahmadi, T.; Al-Rasadi, K.; Johnston, T.P.; Pirro, M.; Sahebkar, A. Antiviral effects of statins. Prog. Lipid Res. 2020, 79, 101054. [CrossRef]

9. Gorabi, A.M.; Kiaie, N.; Pirro, M.; Bianconi, V.; Jamialahmadi, T.; Sahebkar, A. Effects of statins on the biological features of mesenchymal stem cells and therapeutic implications. Hear. Fail. Rev. 2020, 1-14. [CrossRef]

10. Kouhpeikar, H.; Delbari, Z.; Sathyapalan, T.; Simental-Mendía, L.E.; Jamialahmadi, T.; Sahebkar, A. The Effect of Statins through Mast Cells in the Pathophysiology of Atherosclerosis: A Review. Curr. Atheroscler. Rep. 2020, 22, 1-8. [CrossRef]

11. Sahebkar, A.; Serban, C.; Ursoniu, S.; Mikhailidis, D.P.; Undas, A.; Lip, G.Y.H.; Bittner, V.; Ray, K.K.; Watts, G.F.; Hovingh, G.K.; et al. The impact of statin therapy on plasma levels of von Willebrand factor antigen. Thromb. Haemost. 2016, 115, 520-532. [CrossRef]

12. Skowerski, T.; Skowerski, M.; Grzywocz, P.; Kułach, A.; Gąsior, Z. Acute pericarditis in a young patient with IgG immunodeficiency. Arch. Med. Sci. 2020, 16, 1461-1463. [CrossRef] [PubMed]

13. Adam, O.; Neuberger, H.-R.; Böhm, M.; Laufs, U. Prevention of Atrial Fibrillation With 3-Hydroxy-3-Methylglutaryl Coenzyme A Reductase Inhibitors. Circulation 2008, 118, 1285-1293. [CrossRef] [PubMed]

14. Groves, D.; Mihos, C.G.; Larrauri-Reyes, M.; Santana, O. The Use of Statins in the Treatment and Prevention of Atrial Fibrillation. Cardiol. Rev. 2016, 24, 224-229. [CrossRef] [PubMed]

15. Wong, C.X.; Ganesan, A.N.; Selvanayagam, J.B. Epicardial fat and atrial fibrillation: Current evidence, potential mechanisms, clinical implications, and future directions. Eur. Hear. J. 2016, 38, 1294-1302. [CrossRef]

16. Soucek, F.; Covassin, N.; Singh, P.; Ruzek, L.; Kara, T.; Suleiman, M.; Lerman, A.; Koestler, C.; Friedman, P.A.; Lopez-Jimenez, F.; et al. Effects of Atorvastatin $(80 \mathrm{mg})$ Therapy on Quantity of Epicardial Adipose Tissue in Patients Undergoing Pulmonary Vein Isolation for Atrial Fibrillation. Am. J. Cardiol. 2015, 116, 1443-1446. [CrossRef]

17. Hu, Y.-F.; Chen, Y.-J.; Lin, Y.-J.; Chen, S.-A. Inflammation and the pathogenesis of atrial fibrillation. Nat. Rev. Cardiol. 2015, 12, 230-243. [CrossRef] [PubMed]

18. Nattel, S.; Harada, M. Atrial Remodeling and Atrial Fibrillation. J. Am. Coll. Cardiol. 2014, 63, 2335-2345. [CrossRef]

19. Harada, M.; Van Wagoner, D.R.; Nattel, S. Role of Inflammation in Atrial Fibrillation Pathophysiology and Management. Circ. J. 2015, 79, 495-502. [CrossRef] [PubMed]

20. Chaldoupi, S.-M.; Loh, P.; Hauer, R.N.W.; De Bakker, J.M.T.; Van Rijen, H.V.M. The role of connexin40 in atrial fibrillation. Cardiovasc. Res. 2009, 84, 15-23. [CrossRef]

21. Wu, J.H.Y.; Marchioli, R.; Silletta, M.G.; Macchia, A.; Song, X.; Siscovick, D.S.; Harris, W.S.; Masson, S.; Latini, R.; Albert, C.; et al. Plasma Phospholipid Omega-3 Fatty Acids and Incidence of Postoperative Atrial Fibrillation in the OPERA Trial. J. Am. Hear. Assoc. 2013, 2, e000397. [CrossRef] [PubMed]

22. Nomani, H.; Mohammadpour, A.H.; Moallem, S.M.H.; Sahebkar, A. Anti-inflammatory drugs in the prevention of post-operative atrial fibrillation: A literature review. Inflammopharmacology 2020, 28, 111-129. [CrossRef]

23. Jain, M.K.; Ridker, P.M. Anti-Inflammatory Effects of Statins: Clinical Evidence and Basic Mechanisms. Nat. Rev. Drug Discov. 2005, 4, 977-987. [CrossRef]

24. Reiner, Željko Statins in the primary prevention of cardiovascular disease. Nat. Rev. Cardiol. 2013, 10, 453-464. [CrossRef] [PubMed]

25. Zhengming, C.; Jayaram, R.; Jiang, L.; Emberson, J.; Zhao, Y.; Lixin, J.; Du, J.; Guarguagli, S.; Hill, M.; Chen, Z.; et al. Perioperative Rosuvastatin in Cardiac Surgery. New Engl. J. Med. 2016, 374, 1744-1753. [CrossRef] [PubMed]

26. Mannacio, V.A.; Iorio, D.; De Amicis, V.; Di Lello, F.; Musumeci, F. Effect of rosuvastatin pretreatment on myocardial damage after coronary surgery: A randomized trial. J. Thorac. Cardiovasc. Surg. 2008, 136, 1541-1548. [CrossRef] 
27. Sun, Y.; Ji, Q.; Mei, Y.; Wang, X.; Feng, J.; Cai, J.; Chi, L. Role of preoperative atorvastatin administration in protection against post-operative atrial fibrillation following conventional coronary artery bypass grafting. Int. Heart J. 2011, 52, 7-11. [CrossRef] [PubMed]

28. Pierri, M.D.; Crescenzi, G.; Zingaro, C.; D’Alfonso, A.; Capestro, F.; Scocco, V.; Brugia, M.; Torracca, L. Prevention of atrial fibrillation and inflammatory response after on-pump coronary artery bypass using different statin dosages: A randomized, controlled trial. Gen. Thorac. Cardiovasc. Surg. 2016, 64, 395-402. [CrossRef]

29. Billings, F.T.; Hendricks, P.A.; Schildcrout, J.S.; Shi, Y.; Petracek, M.R.; Byrne, J.G.; Brown, N.J. High-Dose Perioperative Atorvastatin and Acute Kidney Injury Following Cardiac Surgery. JAMA 2016, 315, 877-888. [CrossRef]

30. Dehghani, M.R.; Kasianzadeh, M.; Rezaei, Y.; Sepehrvand, N. Atorvastatin Reduces the Incidence of Postoperative Atrial Fibrillation in Statin-Naive Patients Undergoing Isolated Heart Valve Surgery. J. Cardiovasc. Pharmacol. Ther. 2014, 20, 465-472. [CrossRef]

31. Aydin, U.; Yilmaz, M.; Duzyol, C.; Ata, Y.; Turk, T.; Orhan, A.L.; Kocogulları, C.U. Efficiency of postoperative statin treatment for preventing new-onset postoperative atrial fibrillation in patients undergoing isolated coronary artery bypass grafting: A prospective randomized study. Anatol. J. Cardiol. 2015, 15, 491-495. [CrossRef] [PubMed]

32. Xia, J.; Qu, Y.; Shen, H.; Liu, X. Patients with Stable Coronary Artery Disease Receiving Chronic Statin Treatment Who Are Undergoing Noncardiac Emergency Surgery Benefit from Acute Atorvastatin Reload. Cardiology 2014, 128, 285-292. [CrossRef]

33. Baran, C.; Durdu, S.; Dalva, K.; Zaim, Ç.; Dogan, A.; Ocakoğlu, G.; Gürman, G.; Arslan, Ö.; Akar, A.R.; Zaim, C.; et al. Effects of Preoperative Short Term Use of Atorvastatin on Endothelial Progenitor Cells after Coronary Surgery: A Randomized, Controlled Trial. Stem Cell Rev. Rep. 2011, 8, 963-971. [CrossRef]

34. Vukovic, P.M.; Maravic-Stojkovic, V.R.; Peric, M.S.; Jovic, M.D.; Cirkovic, M.V.; Gradinac, S.D.; Djukanovic, B.P.; Milojevic, P.S. Steroids and statins: An old and a new anti-inflammatory strategy compared. Perfusion 2010, 26, 31-37. [CrossRef]

35. Kourliouros, A.; Valencia, O.; Hosseini, M.T.; Mayr, M.; Sarsam, M.; Camm, J.; Jahangiri, M. Preoperative high-dose atorvastatin for prevention of atrial fibrillation after cardiac surgery: A randomized controlled trial. J. Thorac. Cardiovasc. Surg. 2011, 141, 244-248. [CrossRef] [PubMed]

36. Patti, G.; Chello, M.; Candura, D.; Pasceri, V.; D'Ambrosio, A.; Covino, E.; Di Sciascio, G. Randomized Trial of Atorvastatin for Reduction of Postoperative Atrial Fibrillation in Patients Undergoing Cardiac Surgery. Circulation 2006, 114, $1455-1461$. [CrossRef]

37. Zhen-Han, L.; Rui, S.; Dan, C.; Xiao-Li, Z.; Qing-Chen, W.; Bo, F. Perioperative statin administration with decreased risk of postoperative atrial fibrillation, but not acute kidney injury or myocardial infarction: A meta-analysis. Sci. Rep. 2017, 7, 10091. [CrossRef]

38. Yuan, X.; Du, J.; Liu, Q.; Zhang, L. Defining the role of perioperative statin treatment in patients after cardiac surgery: A meta-analysis and systematic review of 20 randomized controlled trials. Int. J. Cardiol. 2017, 228, 958-966. [CrossRef]

39. Rezaei, Y.; Gholami-Fesharaki, M.; Dehghani, M.R.; Arya, A.; Haghjoo, M.; Arjmand, N. Statin Antiarrhythmic Effect on Atrial Fibrillation in Statin-Naive Patients Undergoing Cardiac Surgery. J. Cardiovasc. Pharmacol. Ther. 2016, 21, 167-176. [CrossRef] [PubMed]

40. Bokeriya, O.L.; Akhobekov, A.A.; Shvarts, V.A.; Glushko, L.A.; Le, T.G. Meta-analysis of clinical studies on the use of statins for prevention of atrial fibrillation soon after coronary bypass surgery. Klin. Med. 2016, 94, 85-92. [CrossRef]

41. Putzu, A.; Capelli, B.; Belletti, A.; Cassina, T.; Ferrari, E.; Gallo, M.; Casso, G.; Landoni, G. Perioperative statin therapy in cardiac surgery: A meta-analysis of randomized controlled trials. Crit. Care 2016, 20, 395. [CrossRef]

42. Elgendy, I.Y.; Mahmoud, A.; Huo, T.; Beaver, T.M.; Bavry, A.A. Meta-Analysis of 12 Trials Evaluating the Effects of Statins on Decreasing Atrial Fibrillation After Coronary Artery Bypass Grafting. Am. J. Cardiol. 2015, 115, 1523-1528. [CrossRef] [PubMed]

43. Fauchier, L.; Clementy, N.; Babuty, D. Statin therapy and atrial fibrillation. Curr. Opin. Cardiol. 2013, 28, 7-18. [CrossRef]

44. Goh, S.L.; Yap, K.H.; Chua, K.C.; Chao, V.T. Does preoperative statin therapy prevent postoperative atrial fibrillation in patients undergoing cardiac surgery? Interact. Cardiovasc. Thorac. Surg. 2014, 20, 422-428. [CrossRef]

45. Kuhn, E.W.; Liakopoulos, O.J.; Stange, S.; Deppe, A.-C.; Slottosch, I.; Scherner, M.; Choi, Y.-H.; Wahlers, T. Meta-Analysis of Patients Taking Statins Before Revascularization and Aortic Valve Surgery. Ann. Thorac. Surg. 2013, 96, 1508-1516. [CrossRef] [PubMed]

46. Patti, G.; Bennett, R.; Seshasai, S.R.K.; Cannon, C.P.; Cavallari, I.; Chello, M.; Nusca, A.; Mega, S.; Caorsi, C.; Spadaccio, C.; et al. Statin pretreatment and risk of in-hospital atrial fibrillation among patients undergoing cardiac surgery: A collaborative meta-analysis of 11 randomized controlled trials. Europace 2015, 17, 855-863. [CrossRef]

47. Zheng, H.; Xue, S.; Hu, Z.-L.; Shan, J.-G.; Yang, W.-G. The Use of Statins to Prevent Postoperative Atrial Fibrillation After Coronary Artery Bypass Grafting. J. Cardiovasc. Pharmacol. 2014, 64, 285-292. [CrossRef]

48. Yang, Q.; Qi, X.; Li, Y. The preventive effect of atorvastatin on atrial fibrillation: A meta-analysis of randomized controlled trials. BMC Cardiovasc. Disord. 2014, 14, 99. [CrossRef] [PubMed]

49. Liu, T.; Korantzopoulos, P.; Li, L.; Li, G. Preventive effects of rosuvastatin on atrial fibrillation: A meta-analysis of randomized controlled trials. Int. J. Cardiol. 2013, 167, 3058-3060. [CrossRef]

50. Wang, J.; Wang, A.-R.; Zhang, M.-J.; Li, Y. Effects of Atorvastatin on Serum High-Sensitive C-Reactive Protein and Total Cholesterol Levels in Asian Patients With Atrial Fibrillation. Am. J. Ther. 2017, 24, e20-e29. [CrossRef] [PubMed] 
51. Raiten, J.M.; Ghadimi, K.; Augoustides, J.G.; Ramakrishna, H.; Patel, P.A.; Weiss, S.J.; Gutsche, J.T. Atrial Fibrillation After Cardiac Surgery: Clinical Update on Mechanisms and Prophylactic Strategies. J. Cardiothorac. Vasc. Anesthesia 2015, $29,806-816$. [CrossRef] [PubMed]

52. Kunt, A.; Özcan, S.; Küçüker, A.; Odabaşi, D.; Kunt, A.S. Effects of perioperative statin treatment on postoperative atrial fibrillation and cardiac mortality in patients undergoing coronary artery bypass grafting: A propensity score analysis. Med. Glas. Off. Publ. Med. Assoc. Zenica-Doboj Canton Bosnia Herzeg. 2015, 12, 190-195.

53. Kuhn, E.W.; Slottosch, I.; Wahlers, T.; Liakopoulos, O.J. Preoperative statin therapy for patients undergoing cardiac surgery. Cochrane Database Syst. Rev. 2016, CD008493. [CrossRef] [PubMed]

54. Tamura, K.; Arai, H.; Ito, F.; Someya, T.; Ushiyama, T.; Miyagi, N. Pravastatin treatment before coronary artery bypass grafting for reduction of postoperative atrial fibrillation. Gen. Thorac. Cardiovasc. Surg. 2010, 58, 120-125. [CrossRef]

55. Birmingham, B.K.; Bujac, S.R.; Elsby, R.; Azumaya, C.T.; Zalikowski, J.; Chen, Y.; Kim, K.; Ambrose, H.J. Rosuvastatin pharmacokinetics and pharmacogenetics in Caucasian and Asian subjects residing in the United States. Eur. J. Clin. Pharmacol. 2015, 71, 329-340. [CrossRef]

56. Peña, J.M.; MacFadyen, J.; Glynn, R.J.; Ridker, P.M. High-sensitivity C-reactive protein, statin therapy, and risks of atrial fibrillation: An exploratory analysis of the JUPITER trial. Eur. Hear. J. 2011, 33, 531-537. [CrossRef] [PubMed]

57. Zhao, G.; Wu, L.; Liu, Y.; Gao, L.; Chen, Y.; Yao, R.; Zhang, Y. Rosuvastatin reduces the recurrence rate following catheter ablation for atrial fibrillation in patients with heart failure. Biomed. Rep. 2017, 6, 346-352. [CrossRef] [PubMed]

58. Abacı, O.; Kocas, C.; Oktay, V.; Yıldı, C.E.; Kilickesmez, K.O.; Coskun, U.; Yıldız, A.; Yiǧit, Z. Comparison of Rosuvastatin versus Atorvastatin for Preventing Postoperative Atrial Fibrillation. Hear. Surg. Forum 2013, 16, 158. [CrossRef] [PubMed]

59. Wang, Z.; Zhang, Y.; Gao, M.; Wang, J.; Wang, Q.; Wang, X.; Su, L.; Hou, Y. Statin Therapy for the Prevention of Atrial Fibrillation: A Meta-analysis of Randomized Controlled Trials. Pharmacother. J. Hum. Pharmacol. Drug Ther. 2011, 31, 1051-1062. [CrossRef] [PubMed]

60. Komatsu, T.; Tachibana, H.; Sato, Y.; Ozawa, M.; Kunugita, F.; Nakamura, M. Long-term efficacy of upstream therapy with lipophilic or hydrophilic statins on antiarrhythmic drugs in patients with paroxysmal atrial fibrillation: Comparison between atorvastatin and pravastatin. Int. Heart J. 2011, 52, 359-365. [CrossRef]

61. Liao, J.K.; Laufs, U. PLEIOTROPIC EFFECTS OF STATINS. Annu. Rev. Pharmacol. Toxicol. 2005, 45, 89-118. [CrossRef] [PubMed]

62. Vasnawala, H.; Kavalipati, N.; Shah, J.; Ramakrishan, A. Pleiotropic effects of statins. Indian J. Endocrinol. Metab. 2015, 19, 554-562. [CrossRef]

63. Fujita, M.; Morimoto, T.; Ikemoto, M.; Takeda, M.; Ikai, A.; Miwa, K. Dose-dependency in pleiotropic effects of atorvastatin. Int. J. Angiol. 2007, 16, 89-91. [CrossRef] [PubMed]

64. Chen, W.T.; Krishnan, G.M.; Sood, N.; Kluger, J.; Coleman, C.I. Effect of statins on atrial fibrillation after cardiac surgery: A duration- and dose-response meta-analysis. J. Thorac. Cardiovasc. Surg. 2010, 140, 364-372. [CrossRef] [PubMed]

65. Mithani, S.; Akbar, M.S.; Johnson, D.J.; Kuskowski, M.; Apple, K.K.; Bonawitz-Conlin, J.; Ward, H.B.; Kelly, R.F.; McFalls, E.O.; Bloomfield, H.E.; et al. Dose dependent effect of statins on postoperative atrial fibrillation after cardiac surgery among patients treated with beta blockers. J. Cardiothorac. Surg. 2009, 4, 61. [CrossRef] [PubMed]

66. Tomita, Y.; Maeda, K.; Sugiyama, Y. Ethnic Variability in the Plasma Exposures of OATP1B1 Substrates Such as HMG-CoA Reductase Inhibitors: A Kinetic Consideration of Its Mechanism. Clin. Pharmacol. Ther. 2012, 94, 37-51. [CrossRef] [PubMed]

67. Sui, S.-M.; Wen, J.-H.; Li, X.-H.; Xiong, Y.-Q. Effect of OATP1B1 521T -> C heterogenesis on pharmacokinetic characterstics of rosuvastatin in Chinese volunteers. Acta Pharm. Sin. 2011, 46, 695-700.

68. Lee, E.; Ryan, S.; Birmingham, B.; Zalikowski, J.; March, R.; Ambrose, H.; Moore, R.; Lee, C.; Chen, Y.; Schneck, D. Rosuvastatin pharmacokinetics and pharmacogenetics in white and Asian subjects residing in the same environment. Clin. Pharmacol. Ther. 2005, 78, 330-341. [CrossRef]

69. Panizo, N.; Rubio-Navarro, A.; Amaro-Villalobos, J.M.; Egido, J.; Moreno, J.A. Molecular Mechanisms and Novel Therapeutic Approaches to Rhabdomyolysis-Induced Acute Kidney Injury. Kidney Blood Press. Res. 2015, 40, 520-532. [CrossRef] 